\title{
EVALUASI EFEKTIVITAS PELATIHAN KAMPUNG KB DI PERWAKILAN BKKBN PROVINSI JAWA TIMUR
}

\author{
EVALUATION OF EFFECTIVENESS KAMPUNG KB TRAINING BKKBN \\ EAST JAVA PROVINCE
}

\author{
Thiara Angisna \\ Departemen Biostatistika dan Kependudukan \\ Fakultas Kesehatan Masyarakat Universitas Airlangga, Surabaya \\ Email: thiara.angisna@gmail.com
}

\begin{abstract}
Kampung KB is a government program in which the planning of the formation is needed training as the basic of field implementers to run the programs in accordancethe government's efforts to increase the use of modern KB andpromote development in suburbs. Kampung KB training is expected to assist coordination of agencies or related sectors of development, so its implementation can be done according to plan. Purpose of this study is to analyze the characteristics of the Kampung KB training participants and to analyze the results between pre and post training for the whole participants of Kampung KB training. This type of research uses descriptive observational research design. Population of the research is all participants of 7th and 8 th generation Kampung KB training in 2017. Sample in this research is total population, there are 53 participants. Variable of this research is the effectiveness of the training that include knowledge of participants about Kampung KB. The instrument of this research is questionnaire. This research using a univariable analysis which explain the characteristics of knowledge variable of Kampung KB training. Results of this research are: 1) background or characteristics of participants can affect the level of understanding in accept the given material. 2) enhancement knoeledge of participants is more than expected target, that is 33.9\%. 3) Most of the training participants are quite able to answer the training question material that has been given with the increase already more than $84.91 \%$ of 45 participants. 4) From this evaluation, discovered some question item that is not understood by the participant. The conclusion of this research is learning achievement of the training participants about kampung $K B$ have increased and reach a predetermined target, but more than $25 \%$ of the questions are understood by the participants.
\end{abstract}

Keywords: evaluation of effectiveness training, kampung $K B$

\begin{abstract}
Abstrak: Kampung KB merupakan program pemerintah yang dalam perencanaan pembentukannya diperlukan pelatihan sebagai dasar pelaksana lapangan untuk menjalankan program yang sesuai dengan upaya Pemerintah untuk menaikkan angka pemakaian KB modern dan memajukan pembangunan pada daerah pinggiran. Pelatihan Kampung KB diharapkan dapat membantu dalam koordinasi instansi atau sektor terkait pembangunan, agar dalam pelaksanaan di lapangan dapat dilakukan sesuai rencana dan sesuai bidangnya. Tujuan penelitian ini adalah menganalisis karakteristik peserta pelatihan Kampung KB dan menganalisis hasil sebelum serta sesudah pemberian materi pelatihan Kampung KB seluruh peserta. Jenis penelitian menggunakan desain penelitian observasional deskriptif. Populasi dalam penelitian ini adalah seluruh peserta pelatihan Kampung KB angkatan 7-8 tahun 2017 sebanyak 53 peserta. Jumlah sampel pada penelitian ini menggunakan total populasi. Dalam penelitian ini variabel yang digunakan adalah efektivitas pelatihan yaitu pengetahuan tentang Kampung KB. Instrumen yang digunakan untuk pengumpulan data adalah kuisioner. Penelitian ini menggunakan analisa univariabel yang bertujuan untuk menjelaskan karakteristik variabel pengetahuan pelatihan Kampung KB. Berdasarkan hasil penelitian menunjukkan bahwa: 1) Latar belakang atau karakteristik peserta dapat mempengaruhi tingkat pemahaman dalam menerima materi yang disampaikan. 2) Kenaikan pengetahuan peserta melebihi target yang diharapkan, yaitu sebesar 33,9\% pada hasil akhir pengetahuan. 3) Sebagian besar peserta pelatihan cukup mampu menjawab materi pertanyaan pelatihan yang telah diberikan dengan kenaikan sudah lebih dari 84,91\% sejumlah 45 peserta. 4) Pada evaluasi materi per butir pertanyaan terdapat beberapa materi pertanyaan yang kurang dipahami peserta, sehingga masih penurunan kesalahan yang tidak memenuhi target minimal kenaikan pengetahuan. Kesimpulan yang dapat diambil yaitu secara umum hasil perolehan hasil belajar para peserta pelatihan sudah meningkat, akan tetapi hasil menunjukkan lebih dari $25 \%$ pertanyaan kurang dapat dipahami peserta.
\end{abstract}

Kata kunci: evaluasi efektivitas pelatihan, kampung KB 


\section{PENDAHULUAN}

Program Kependudukan Keluarga Berencana dan Pembangunan Keluarga merupakan program kebijakan pemerintah untuk menekan laju pertumbuhan Indonesia. Program Keluarga Berencana merupakan upaya perencanaan kependudukan yang sangat strategis, komprehensif, dan fundamental untuk mewujudkan masyarakat Indonesia yang sehat dan sejahtera. Rencana Pembangunan Jangka Menengah Nasional (RPJMN) dan Rencana Strategis (Renstra) BKKBN tahun 2015-2019 dalam Juknis Kampung KB (2016) menetapkan 6 sasaran strategis program yaitu:

1. Menurunkan rerata laju pertumbuhan penduduk di tingkat nasional dari 1,38 persen per tahun pada tahun 2015 menjadi 1,21 persen pada tahun 2019 .

2. Menurunnya angka Total Fertility Rate (TFR) yang semula pada tahun 2015 sebesar 2,37 menjadi 2,28 tahun 2019.

3. Meningkatnya Contraceptive Prevalence Rate (CPR) semua metoda dari 65,2 persen menjadi 66 persen.

4. Menurunnya angka kebutuhan ber-KB tidak terlayani/unmet need dari jumlah pasangan usia subur dari 10,6 persen pada tahun 2015 menjadi 9,91 persen tahun 2019.

5. Menurunnya Age Specific Fertility Rate (ASFR) dari 46 (pada tahun 2015) menjadi 38 per 1.000 perempuan kelompok umur 15-19 tahun pada tahun 2019.

6. Menurunnya persentase kehamilan yang tidak diinginkan dari Wanita Usia Subur dari 7,1 persen pada tahun 2015 menjadi 6,6 persen di tahun 2019 .

Menurut laporan survei Rencana Pembangunan Jangka Menengah Nasional (RPJMN) 2016, angka pemakaian KB menggunakan semua metode sebesar 60,9 persen, angka pemakaian kontrasepsi yang dipakai wanita pasangan usia subur terdiri dari metode tradisional 1,4 persen dan kontrasepsi modern 59,5 persen. Cakupan penggunaan kontrasepsi modern nasional 2016 masih berada di bawah standart target nasional yaitu sebesar 60,7 persen. Dalam pelaksanaan program Kependudukan Keluarga Berencana dan Pembangunan
Keluarga terdapat beberapa program untuk meningkatkan angka pemakaian KB modern yang didasari oleh Nawa cita ke 3 yaitu "memulai pembangunan dari pinggiran dengan memperkuat daerah-daerah dan desa dalam kerangka negara kesatuan", ke 5, yaitu "meningkatkan kualitas hidup masyarakat Indonesia", dan menggairahkan kembali program KB guna menyongsong tercapainya bonus demografi yang diprediksi akan terjadi pada tahun 2010-2030.

Program Kampung KB dikelola oleh BKKBN (Kementerian Koordinator bidang Pembangunan Manusia dan Kebudayaan) mulai dilaksanakan tahun 2016. Dalam pelaksanaannya diharapkan dapat menyusun suatu kegiatan-kegiatan yang dapat meningkatkan target atau sasaran dengan cara bersentuhan langsung dengan masyarakat sehingga manfaatnya dapat langsung dirasakan oleh masyarakat. Secara umum Kampung KB ditujukan untuk keluarga, kelompok Pasangan Usia Subur (PUS), lansia (lanjut usia), remaja dan juga keluarga yang mempunyai balita. Untuk sasaran sektoral Kampung KB ditujukan kepada sektor terkait seperti Kepala Desa, ketua RW, ketua RT, Penyuluh Keluar Berencana (PKB), petugas lapangan seperti Pembinaan Kesejahteraan Keluarga (PKK), kader, tokoh agama, tokoh masyarakat, pemuda serta kader pembangunan lainnya.

Kriteria wilayah Kampung KB dalam memilih atau menentukan wilayah yang akan dijadikan lokasi Kampung KB ada tiga kriteria yang dipakai, antara lain:

a. Kriteria utama

Mencakup dua hal yaitu yang pertama jumlah keluarga pra sejahtera dan KS 1 (miskin) di atas rata-rata pra sejahtera dan KS 1 tingkat desa/kelurahan di mana kampung tersebut berada, kedua jumlah peserta KB di bawah rata-rata pencapaian peserta KB tingkat desa/kelurahan di mana Kampung KB tersebut berlokasi.

b. Kriteria wilayah

Kriteria ini mencakup 10 kategori wilayah yaitu daerah kumuh, pesisir, daerah aliran sungai (DAS), bantaran kereta api, kawasan miskin (termasuk miskin perkotaan), (6) Terpencil, perbatasan, kawasan industri, kawasan wisata, padat penduduk. Selanjutnya 
dalam menentukan kriteria wilayah yang akan dijadikan sebagai lokasi pembentukan Kampung KB dapat dipilih satu atau lebih dari sepuluh kriteria yang ada.

c. Kriteria Khusus

Mencakup 5 hal, yaitu: kriteria data di mana setiap RT/RW memiliki Data dan Peta Keluarga, kriteria kependudukan di mana angka partisipasi penduduk usia sekolah rendah, kriteria program KB di mana peserta KB aktif dan Metode Kontrasepsi Jangka Panjang (MKJP) lebih rendah dari capaian rata-rata tingkat desa/kelurahan serta tingkat unmet need lebih tinggi dari rata-rata tingkat desa/kelurahan, kriteria program pembangunan keluarga di mana partisipasi keluarga dalam pembinaan ketahanan keluarga, pemberdayaan ekonomi dan partisipasi remaja dalam kegiatan Pusat Informasi dan Konseling Remaja (PIK-R) masih rendah, dan yang terakhir kriteria program pembangunan sektor terkait yang mencakup setidaknya empat bidang, yakni kesehatan, ekonomi, pendidikan, pemukiman dan lingkungan, dan masih bisa ditambah dengan program lainnya sesuai dengan perkembangan.

BKKBN menyatakan bahwa definisi Kampung KB adalah wilayah setingkat desa atau yang setingkat yang memiliki kriteria tertentu di mana terdapat keterpaduan program Kependudukan Keluarga Berencana dan Pembangunan Keluarga (KKBPK) dan pembangunan sektor terkait yang dilaksanakan secara sistemik dan sistematis (Juknis Kampung KB, 2015). Setelah diresmikan pada bulan Januari 2016, pelaksanaan program dan kegiatan Kampung KB Triwulan I 2017 dilaporkan sudah terdapat 633 yang telah dicanangkan. Target pencanangan dan pembentukan Kampung KB adalah satu Kampung KB di setiap kecamatan.

Desa atau kampung yang di Indonesia yang sudah terdapat Kampung KB tercatat sebanyak 1.200, angka ini masih jauh dari jumlah kecamatan yang ada di Indonesia. Pembentukan Kampung KB diperlukan perencanaan dan kerja sama dari berbagai pihak pemangku kepentingan atau lintas sektor, seperti Satuan Kerja Perangkat Daerah Keluarga Berencana (SKPDKB) kabupaten/kota, Penyuluh Lapangan Keluarga Berencana (PLKB), kecamatan, RT, RW, kader dan lain sebagainya. Beberapa hal yang dapat dilakukan sebagai dasar untuk acuan pembentukan dan pelaksanaan Kampung KB yaitu diberikannya pelatihan Kampung KB.

Pelatihan Kampung KB merupakan suatu dasar yang diberikan pada pelaksana lapangan agar dapat melaksanakan dan merencanakan suatu kegiatan yang terstruktur dan hasilnya dapat dirasakan serta dimanfaatkan oleh masyarakat guna meningkatkan pembangunan dan kualitas sumber daya manusia di daerah kampung atau pelosok. Pelatihan Kampung KB diberikan kepada pelaksana daerah dalam beberapa jenjang oleh karena itu pelatihan untuk peserta diberikan materi yang sesuai dengan jenjang atau tupoksi yang sesuai agar pemanfaatan pelatihan dapat dipahami dan dilaksanakan. Pelatihan Kampung KB diharapkan dapat membantu dalam koordinasi instansi atau sektor terkait pembangunan, agar dalam pelaksanaan di lapangan dapat dilakukan sesuai rencana dan sesuai bidangnya.

Pencapaian keberhasilan suatu program salah satunya dapat dipengaruhi oleh keahlian atau kemampuan dari pelaksana program tersebut. Pelatihan merupakan salah satu upaya yang dapat dilakukan untuk meningkatkan kemampuan atau keahlian dari pelaksana. Rivai dan Sagala (2011) menyebutkan bahwa pelatihan memiliki orientasi saat ini sehingga sesuai dengan keadaan yang dihadapi dan dapat membantu pegawai untuk memperoleh keahlian dan kemampuan tertentu agar pekerjaan yang dilakukan berhasil.

Simmamora (2010:4) menyebutkan bahwa pelatihan meliputi serangkaian aktivitas yang dirancang untuk meningkatkan keahlian, pengetahuan, pengalaman dan perilaku seseorang (karyawan). Pelaksanaan pelatihan oleh suatu instansi dilakukan berdasarkan keinginan instansi atau organisasi atas adanya perubahan prestasi kerja karyawan sehingga tujuan dari instansi atau organisasi tersebut dapat tercapai. 
Sedarmayanti (2013) menyebutkan bahwa tujuan dari pelaksanaan pelatihan adalah mempersiapkan sumber daya pelaksana tugas agar dapat mengerjakan pekerjaan yang telah dibebankan dengan baik dan terstruktur. Untuk peserta diberikan materi yang sesuai dengan tupoksi yang sesuai agar materi pelatihan dapat dipahami dan diimplementasikan dengan baik.

Pada hakekatnya effektifitas memiliki makna yang menitikberatkan pada tingkat keberhasilan dan pencapaian tujuan yang ditetapkan sebelumnya. Richard M. Steers (1995) mengungkapkan bahwa untuk meneliti suatu efektivitas pelatihan organisasi ada tiga konsep yang dapat dilihat untuk mencapai sasaran dan tujuan, yaitu konsep optimisasi tujuan, konsep perspektif sistem, dan tekanan terhadap perilaku.

Dalam menilai efektivitas dari pelatihan yang dilakukan dapat dilakukan suatu evaluasi di mana pelatihan yang efektif dapat dilihat dari manfaat yang dirasakan oleh instansi dan peserta pelatihan. Evaluasi program dapat dilakukan dengan mengukur hasil atau kriteria spesifik untuk menentukan keuntungan dari program pelatihan. Evaluasi program pelatihan merupakan suatu pendekatan penilaian dengan melihat proses dalam pelaksanaan pelatihan serta dampak atau pengaruh yang dihasilkan dari pelaksanaan pelatihan terhadap pekerjaan yang ditugaskan.

Menurut Fauzi (2011), fungsi utama evaluasi adalah memberikan data informasi yang benar mengenai pelaksanaan suatu pelatihan sehingga penyelenggaraan pelatihan tersebut dapat mengambil keputusan yang tepat apakah pelatihan tersebut akan diteruskan, ditunda atau sama sekali tidak dilaksanakan lagi. Oleh karena itu, evaluasi pelatihan berfungsi sebagai suatu usaha untuk:

a. Menentukan tingkat kemajuan pelaksanaan pelatihan. Dalam hal ini juga dapat untuk mengetahui bahwa pelaksanaan pelatihan dalam meningkatkan pengetahuan, keterampilan dan perilaku peserta adalah suatu investasi yang sesuai dengan besaran biaya yang dikeluarkan untuk pelaksanaan pelatihan. b. Menemukan faktor pendorong dan penghambat pelaksanaan pelatihan

c. Menemukan penyimpangan atau kekeliruan pelaksanaan pelatihan

d. Memperoleh bahan untuk penyusunan saran perbaikan, perubahan, penghentian atau perluasan pelatihan. Keberlangsungan kegiatan pelatihan dilihat berdasarkan manfaat dari pelaksanaan pelatihan tersebut, jika memang tidak ada nilai atau manfaat yang dihasilkan maka pelatihan bisa diberhentikan.

Nana Sudjana \& Ibrahim (2007) menjelaskan bahwa dalam pelaksanaan evaluasi terdapat beberapa dimensi evaluasi, antara lain:

1. Context, merupakan situasi atau latar belakang yang mempengaruhi tujuan dan strategi yang akan dikembangkan dalam kegiatan yang dilaksanakan.

2. Input, merupakan sarana, modal, bahan atau rencana strategi yang ditetapkan saat pelaksanaan kegiatan yang diperlukan untuk mencapai tujuan dari kegiatan.

3. Process, merupakan pelaksanaan dari strategi dan penggunaan sarana, modal dan bahan yang telah direncanakan dalam kegiatan nyata di lapangan.

4. Product, merupakan hasil yang dicapai baik selama proses maupun akhir dari tahap pengembangan kegiatan yang dilakukan.

Penelitian ini bertujuan untuk menganalisis evaluasi efektivitas pelatihan Kampung KB pada angkatan 7-8 di perwakilan BKKBN provinsi Jawa Timur tahun 2017. Evaluasi efektivitas pelatihan berpusat pada evaluasi pengetahuan peserta pelatihan.

\section{METODE}

Penelitian ini dilakukan di Perwakilan Badan Kependudukan dan Keluarga Berencana Nasional Provinsi Jawa Timur pada bulan September 2017. Jenis penelitian yang dilakukan adalah observasional deskriptif, yang bertujuan untuk mengetahui gambaran yang lebih detail mengenai 
suatu gejala atau masalah yang merupakan bagian tujuan dari penelitian. Sumber data penelitian ini menggunakan data primer dengan menggunakan instrument penelitian berupa kuesioner. Populasi dalam penelitian ini adalah seluruh peserta pelatihan Kampung KB angkatan 7 dan 8 tahun 2017 sebanyak 53 peserta. Jumlah sampel pada penelitian ini menggunakan total populasi, sehinga jumlah sampel penelitian berjumlah 53 peserta.

Variabel dalam penelitian ini adalah efektivitas pelatihan yang dinilai berdasarkan pengetahuan peserta tentang materi Kampung KB yang telah diberikan. Variabel ini sesuai dengan tujuan penelitian, seperti pendapat Nitiseito (2000) yang mengatakan bahwa tujuan pelatihan dan pendidikan sangat sesuai dengan tujuan pembinaan pegawai yaitu menambah pengetahuan, keterampilan dan merubah sikap pegawai agar penyelenggaraan tugastugas dan pembangunan dapat berdaya guna dan berhasil guna.

Kuesioner yang digunakan sebagai instrumen penelitian dikembangkan dari buku Modul Belajar Mandiri Kampung KB tahun 2017 dan telah diuji reliabilitas dan validitas. Pertanyaan pengetahuan yang diberikan terdiri dari 30 pertanyaan dalam bentuk pilihan ganda. Proses tabulasi penelitian ini menggunakan scoring, yaitu dilakukan dengan memberikan kode untuk masing-masing variabel. Proses scoring dilakukan untuk memudahkan dalam proses tabulasi. Scoring pada variabel pengetahuan dilakukan dengan memberi nilai 1 untuk jawaban benar dan memberi nilai 0 untuk jawaban salah.

Analisa data yang digunakan untuk tingkat pengetahuan peserta dalam memahami materi yaitu naik bila hasil yang didapatkan 10,00-100,00, tidak naik bila hasil yang didapatkan kurang dari 9,99. Analisa data yang digunakan untuk melihat persentase penurunan jumlah peserta yang menjawab salah yaitu memenuhi bila hasil yang didapat lebih dari $25 \%$ dan tidak memenuhi bila hasil yang didapat kurang dari $25 \%$. Setelah data terkumpul maka dilakukan pengolahan dengan cara editing, coding, entry data, cleaning, tabulating, dan analisa data.
Data yang diperoleh kemudian diperiksa kembali kelengkapannya, kemudian dilakukan pengecekan kembali apakah data yang telah dimasukkan sudah benar atau masih ada kesalahan. Setelah semua data dibersihkan, maka data ditabulasikan dan kemudian akan dianalisis. Data yang telah diperoleh dianalisis menggunakan analisa univariabel. analisa univariabel bertujuan untuk menjelaskan karakteristik variabel pengetahuan pelatihan kampung KB.

\section{HASIL DAN PEMBAHASAN}

\section{Karakteristik Responden}

Setelah penelitian dan pengambilan data selesai, maka akan memperoleh hasil data penelitian. Data tersebut yaitu data pengetahuan peserta pelatihan Kampung KB dengan menggunakan kuesioner pre \& post test. Responden dalam penelitian ini adalah seluruh peserta pelatihan angkatan 7 dan 8 di BKKBN Provinsi Jawa Timur yang telah mengikuti pelatihan Kampung KB sebanyak 53 orang.

Peserta pelatihan yang menjadi responden dibagi menjadi beberapa karakteristik, diantaranya jenis kelamin, usia, pendidikan, dan jabatan. Hal ini digunakan untuk mengetahui distribusi frekuensi dari peserta pelatihan yang menjadi objek dalam penelitian ini. Selain itu dapat digunakan untuk mengetahui karakteristik mana yang dapat mempengaruhi peserta pelatihan dalam memahami dan mempraktekkan materi yang diberikan kepada peserta. Adapun karakteristik responden terdapat pada tabel 1 .

Berdasarkan Tabel.1 diketahui peserta pelatihan Kampung KB yang menjadi responden dalam penelitian ini sebanyak $78 \%$ adalah pria dan $28 \%$ adalah wanita. Hasil tersebut didapatkan hasil bahwa mayoritas peserta pelatihan adalah laki-laki. Tumnkaya, 2012 mengatakan bahwa lakilaki dan perempuan tidak ada perbedaan dalam proses pembelajaran. Karakteristik usia responden dalam penelitian ini sebagian besar berada pada rentang usia 51-55 tahun dengan persentase sebanyak 49\%. Mayoritas 
Tabel 1. Distribusi Frekuensi Karakteristik Peserta

\begin{tabular}{|c|c|c|c|}
\hline Karakteristik & Kategori & f & $(\%)$ \\
\hline \multirow{2}{*}{ Jenis kelamin } & Laki-laki & 38 & 72 \\
\hline & Perempuan & 15 & 28 \\
\hline \multirow{7}{*}{ Usia } & $26-30$ & 0 & 0 \\
\hline & $31-35$ & 0 & 0 \\
\hline & $36-40$ & 0 & 0 \\
\hline & $41-45$ & 2 & 4 \\
\hline & $46-50$ & 21 & 40 \\
\hline & $51-55$ & 26 & 49 \\
\hline & $56-60$ & 4 & 8 \\
\hline \multirow{3}{*}{ Pendidikan } & SMA & 12 & 23 \\
\hline & S1 & 34 & 64 \\
\hline & $\mathrm{S} 2$ & 7 & 13 \\
\hline \multirow{5}{*}{ Jabatan } & Ka. Upt & 19 & 36 \\
\hline & Koordinator & 8 & 15 \\
\hline & Penyuluh & 21 & 40 \\
\hline & Pelaksana & 1 & 2 \\
\hline & $\begin{array}{l}\text { Penanggung } \\
\text { jawab }\end{array}$ & 4 & 8 \\
\hline
\end{tabular}

Keterangan:

Cetak Tebal: Dominan

usia peserta memungkinkan pegawai lebih berpengalaman dalam memahami tingkat karakteristik daerah dan masyarakat, serta lebih memahami dalam menyusun dan melaksanakan kegiatan untuk daerah Kampung KB. Sebagian besar peserta pelatihan didominasi oleh peserta dengan usia 50-55 tahun. Hal ini diharapkan pelaksana program pada usia tersebut lebih memiliki kemantapan dalam berpikir dan pengambilan keputusan. Ratna (2010) menyebutkan bahwa pertambahan usia individu akan meningkatkan kemampuan dan kematangan berpikir serta menyerap informasi dengan lebih baik dibandingkan dengan usia yang di bawahnya.

Pada komponen jabatan, responden didominasi oleh penyuluh KB sebesar $40 \%$ dan Ka UPT sebesar 36\%. Dilihat dari mayoritas komponen jabatan, peserta dari jabatan tersebut diharapkan memiliki skill dan wawasan yang luas dalam perencanaan dan pelaksanaan di daerah Kampung KB. Sebagian besar peserta pelatihan didominasi oleh peserta yang memiliki jabatan atau latar belakang pekerjaan sebagai tenaga penyuluh. Hal ini diharapkan dapat meningkatkan kinerja program dengan cara pengambilan keputusan yang tepat dikarenakan telah memiliki pengalaman yang lebih luas terkait kondisi masyarakat di daerah. Latar belakang dan pengalaman dapat menjadikan seseorang mempunyai kemampuan dalam mengambil keputusan (Arlene, 2001).

Latar belakang peserta memungkinkan menjadi faktor yang dapat mempengaruhi tujuan dari suatu pelatihan. Nana Sudjana \& Ibrahim (2007) mengatakan jenisjenis tujuan dan strategi pendidikan yang akan dikembangkan dalam sistem dapat dipengaruhi dari situasi atau latar belakangnya. Sedangkan tujuan pelatihan ini adalah memberikan pelatihan yang dapat diterima peserta sehingga dapat diaplikasikan di lapangan.

Sebagian besar peserta memiliki jenjang pendidikan S1, Tingkat pendidikan yang tinggi ini memungkinkan peserta dapat lebih mudah memahami materi yang diberikan dan dapat menganalisis tingkat pertanyaan yang diberikan oleh pihak instansi. Secara keseluruhan pelatihan Kampung KB atau materi yang diberikan kepada peserta dapat dipahami. Hasil ini sependapat dengan yang dikemukakan oleh Erfandi (2009) yang menyebutkan bahwa tingkat pendidikan individu mempengaruhi proses belajar yang terjadi, semakin tinggi pendidikan seorang maka semakin mudah orang tersebut untuk menerima informasi yang disampaikan.

\section{Evaluasi Pelatihan}

\section{Pengetahuan}

Konsep belajar menurut Kirkpatrick (2005), pembelajaran dapat diartikan sebagai sejauh mana terjadinya perubahan perilaku, peningkatan pengetahuan dan/atau penambahan kemampuan sebagai hasil dari keterlibatannya dalam program.

Pengetahuan merupakan hasil tahu setiap individu terhadap objek yang didapatkannya melalui alat indra yang dimiliki. Dari hasil tersebut, individu dapat menghasilkan pengetahuan yang dipengaruhi oleh seberapa sering individu tersebut memperhatikan suatu objek (Notoatmodjo, 2010).

Dalam menilai dampak dari pelaksanaan program pelatihan yang diikuti peserta dapat diukur berdasarkan seberapa jauh terjadinya peningkatan pengetahuan, keahlian, dan perilaku (Satriono,dkk, 
2007). Penelitian ini difokuskan pada seberapa jauh pengetahuan peserta dalam memahami isi materi pelatihan Kampung $\mathrm{KB}$, sehingga nantinya dapat digunakan sebagai bahan perencanaan pelatihan yang akan diselenggarakan selanjutnya.

Berdasarkan Gambar 1, diketahui bahwa 53 peserta pelatihan yang diberi materi Kampung KB dilihat dari persentasi rata-rata hasil pre-test dan post-test yang menunjukkan bahwa rata-rata pretest untuk seluruh peserta adalah $33,9 \%$ dan nilai rata-rata post test untuk seluruh peserta adalah $73,6 \%$. Dengan demikian dapat diketahui bahwa terjadi peningkatan pengetahuan peserta tentang aspek-aspek yang berhubungan dengan pemberian materi Kampung KB pada pelatihan yaitu sebesar $39,7 \%$. Kenaikan tersebut dapat dicapai dari materi yang diberikan pada saat pelatihan di dalam kelas ataupun di luar kelas, sehingga dapat diketahui bahwa materi yang diberikan oleh narasumber dapat diterima oleh peserta pelatihan dilihat dari rata-rata naik atau tidaknya hasil persentase setelah materi pelatihan diberikan.

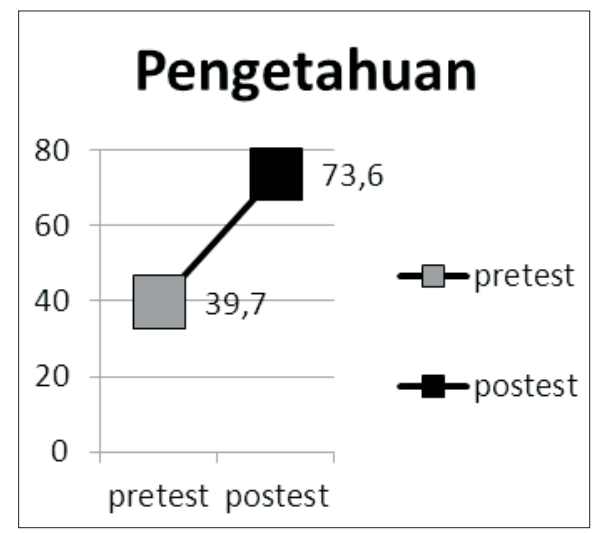

Gambar 1. Kenaikan pengetahuan sebelum dan sesudah pelatihan.

Keterangan:

: rata-rata pengetahuan sebelum pelatihan

- rata-rata pengetahuan sesudah pelatihan

Peningkatan pengetahuan peserta Kampung KB yang secara umum meningkat dapat dipengaruhi oleh karakteristik peserta yang rata-rata berpendidikan S1. Hal ini memungkinkan peserta dapat lebih mudah memahami materi yang diberikan. Selain itu latar belakang pekerjaan yang sejalan dengan pembentukan Kampung KB dapat membuat peserta lebih mudah memahami dan mengaplikasikan dalam menjawab pertanyaan yang diberikan untuk pre dan post test.

Berdasarkan hasil penelitian yang telah dipaparkan, dapat dilihat bahwa tingkat pembelajaran (level learning) atau pemahaman peserta pelatihan terhadap materi pelatihan kampung memberikan hasil yang positif dengan kategori tingkat pembelajaran yang cukup baik sebesar 39,7\%, akan tetapi kenaikan rata-rata pengetahuan masih di bawah harapan yang ditetapkan oleh instansi penyelenggara yaitu dapat menaikkan rata-rata pengetahuan peserta sebesar 50\%. Dari hasil tersebut dapat dikatakan bahwa lebih $25 \%$ dari total jumlah peserta pelatihan mampu menjawab pertanyaan yang diajukan peneliti dan paham mengenai materi pelatihan. Melihat hasil tersebut, pengetahuan peserta dalam memahami materi Kampung KB yang diberikan oleh instansi diharapkan peserta akan mampu menjalankan program Kampung KB di daerah peserta sesuai dengan tujuan dari program Kampung KB.

Teori behavioris yang diperkenalkan oleh Ivan Pavlov dan dikembangkan oleh Thorndike dan Skinner (Churohman, 2010), mengatakan pembelajaran merupakan perubahan tingkah laku seseorang yang mendapatkan pembelajaran yang akan mempengaruhi oleh segala perbuatan atau tingkah laku tetap sama atau ada perubahan setelah diberikan pembelajaran, dengan demikian dapat dilihat tingkah laku yang didapat setelah pembelajaran ke arah positif atau negatif.

Oleh karena itu untuk mengukur efektivitas program pelatihan maka aspek pengetahuan merupakan hal yang penting untuk diukur. Tanpa adanya peningkatan pengetahuan pada peserta pelatihan maka suatu program dapat dikatakan gagal. Pada evaluasi hasil pelatihan Kampung KB ini didapatkan hasil pengetahuan peserta telah meningkat sehingga dapat dikatakan pelatihan Kampung KB sudah cukup efektif. 


\section{Pemahaman}

Evaluasi suatu pelatihan dapat dilihat pemahaman peserta dalam menjawab pertanyaan yang diberikan yang ada di hasil pre dan post test. Jumlah peserta yang mendapatkan hasil peningkatan pengetahuan dapat dijadikan salah satu cara untuk mengevaluasi suatu program pelatihan yang diadakan. Evaluasi ini juga dapat melihat seberapa jauh tingkat efektivitas pelatihan dengan melihat peningkatan pengetahuan peserta dalam menerima materi yang disampaikan. Adapun hasil perolehan dari para peserta berikut hasil peningkatan skor pre dan post-test adalah sebagai berikut:

Berdasarkan Tabel 2, diketahui bahwa hasil pre \& post test peserta pelatihan terdapat beberapa peserta yang pada hasil post test tidak terdapat kenaikan pengetahuan terhadap materi pelatihan yang diberikan. Jumlah peserta yang sebagian besar telah mengalami kenaikan pengetahuan pre dan post test berjumlah 45 peserta sehingga dapat disimpulkan bahwa sebagian besar responden dapat menangkap materi yang diberikan dengan baik. Delapan peserta lain yang tidak mengalami kenaikan pengetahuan baik saat pre dan post test dapat terjadi dikarenakan adanya beberapa faktor yang memengaruhi.

Hasil Tabel 2, menunjukkan bahwa persentase kenaikan pengetahuan peserta terbanyak yaitu pada kategori hasil 30\% dengan jumlah peserta sebanyak 8 peserta. Pada kenaikan pengetahuan dengan kategori hasil $45 \%$ dan $40 \%$ terdapat masing-masing 7 peserta. Mayoritas kategori hasil peserta pre dan post test yang kurang dari 50\% menjadikan hasil tersebut masih tergolong dalam hasil yang cukup dari target yang diharapkan.

Berdasarkan tabel 2, diketahui bahwa masih terdapat 8 peserta yang tidak mengalami peningkatan pada hasil post test. Hal ini dapat terjadi dikarenakan faktor yang dapat berpengaruh yaitu usia peserta, hal tersebut dapat terjadi karena peserta lebih cepat mengalami kebosanan dalam pembelajaran sehingga memungkinkan peserta kurang memahami materi dan menjawab pertanyaan yang diberikan.

Mayoritas umur peserta yang lebih dari 50 tahun membuat peserta merasa lebih
Tabel 2. Distribusi Frekuensi Hasil Pre test dan post test Peserta Pelatihan

\begin{tabular}{|c|c|c|c|}
\hline Kategori & $\begin{array}{c}\text { Hasil } \\
(\%)\end{array}$ & $\begin{array}{c}\text { Kategori Hasil } \\
(\%)\end{array}$ & $\mathbf{F}$ \\
\hline \multirow[t]{12}{*}{ Naik } & 84,91 & 100 & 1 \\
\hline & & 95 & 2 \\
\hline & & 90 & 1 \\
\hline & & 65 & 1 \\
\hline & & 55 & 3 \\
\hline & & 45 & 7 \\
\hline & & 40 & 7 \\
\hline & & 35 & 3 \\
\hline & & 30 & 8 \\
\hline & & 25 & 4 \\
\hline & & 20 & 6 \\
\hline & & 15 & 2 \\
\hline Tidak & 15,09 & 5 & 3 \\
\hline \multirow[t]{2}{*}{ Naik } & & 0 & 2 \\
\hline & & -5 & 3 \\
\hline \multicolumn{4}{|l|}{ Keterangan: } \\
\hline $\mathrm{F}$ & \multicolumn{3}{|c|}{ : Jumlah peserta } \\
\hline Kategori & \multicolumn{3}{|c|}{$\begin{array}{l}\text { Kategori hasil persentase tingkat } \\
\text { kenaikan menjawab hasil pre } \\
\text { dan post test }\end{array}$} \\
\hline Kategori Hasil & \multicolumn{3}{|c|}{$\begin{array}{l}\text { Kategori hasil pembobotan } \\
\text { angka }\end{array}$} \\
\hline Cetak tebal & \multicolumn{3}{|c|}{$\begin{aligned} \text { : Jumlah peserta yang tidak } \\
\text { mengalami kenaikan dalam pre } \\
\text { dan post test lebih dari } 10 \%\end{aligned}$} \\
\hline
\end{tabular}

cepat bosan dalam menerima materi yang dilakukan di dalam ruangan, selain itu waktu saat memberikan materi juga harus menjadi pertimbangan yang sangat penting untuk meningkatkan keefektifan penerimaan materi pelatihan oleh peserta. Selain mengevaluasi persentase tingkat kenaikan pengetahuan peserta juga dapat dilakukan evaluasi yang dilihat per butir pertanyaan untuk melihat dan mencari pertanyaan yang kurang dipahami peserta sehingga dapat menjadi bahan untuk perencanaan ulang strategi dalam pemberian materi agar dapat lebih dipahami oleh peserta.

Jawaban peserta dapat dikelompokkan menjadi dua yaitu jumlah peserta yang menjawab benar dan jumlah peserta yang menjawab salah, hal tersebut dilakukan untuk mengetahui nilai peserta yang 
sebenarnya dan mendapatkan persentase penurunan jumlah peserta yang menjawab salah. Untuk melihat materi tersebut sudah memenuhi target yang diharapkan dapat dilihat dengan melihat peserta yang menjawab benar dan salah pada tiap pertanyaan yang diajukan. Dalam evaluasi materi atau pertanyaan yang diberikan tetap dilakukan kepada seluruh peserta pelatihan angkatan 7-8 di BKKBN Jawa Timur sebanyak 53 orang.

Berdasarkan Tabel 3. Diketahui bahwa tidak adanya frekuensi persentase penurunan jumlah peserta yang menjawab salah dilihat dari pertanyaan terdapat pada nomer 14 , pertanyaannya yaitu "salah satu cara pengendalian program poktan dilakukan melalui" dan pada nomer 21 yang mengalami peningkatan kesalahan yaitu "untuk membangkitkan komitmen pemegang kebijakan terhadap program KB diperlukan", hal ini dapat disebabkan karena peserta belum pernah melakukan implementasi di lapangan terkait dengan materi pertanyaan yang diberikan sehingga para peserta belum terlalu memahami evaluasi yang harus dilakukan terkait materi yang diberikan.

Pada Tabel 3 memperlihatkan hasil analisis distribusi pertanyaan yang di lihat dari per butir pertanyaan yang diberikan. Hasil analisis diketahui bahwa dari total 30 pertanyaan yang diberikan untuk mengukur tingkat pengetahuan peserta terdapat 22 pertanyaan yang mengalami peningkatan, hal tersebut dapat menyatakan bahwa peserta sudah dapat memahami materi pelatihan yang diberikan dengan baik. Hal ini membuktikan bahwa dengan adanya penyelenggaraan Pelatihan Kampung KB efektif dalam meningkatkan pengetahuan peserta pelatihan terhadap materi yang diberikan terkait dengan pelaksanaan Kampung KB. Materi pelatihan yang dilakukan di lapangan secara langsung juga dapat meningkatkan pengetahuan peserta tentang pelaksanaan Kampung KB sesuai dengan kondisi daerah. Pelatihan Kampung KB merupakan bentuk pemberian materi dasar, me-review dan menambah pengetahuan serta keterampilan peserta terhadap hal-hal yang harus dilakukan guna
Tabel 3. Distribusi Presentase penurunan jumlah peserta yang menjawab salah

\begin{tabular}{|c|c|c|c|c|c|c|}
\hline \multirow{2}{*}{$\mathbf{P}$} & \multicolumn{2}{|c|}{ Pre test } & \multicolumn{2}{|c|}{ Post test } & \multirow[b]{2}{*}{$(\%)$} & \multirow{2}{*}{ ket } \\
\hline & B & $\mathbf{S}$ & B & $\mathbf{S}$ & & \\
\hline 1 & 33 & 20 & 46 & 7 & 35 & M \\
\hline 2 & 13 & 40 & 35 & 18 & 45 & M \\
\hline 3 & 33 & 20 & 40 & 13 & 65 & M \\
\hline 4 & 6 & 47 & 16 & 37 & 79 & BM \\
\hline 5 & 24 & 29 & 44 & 9 & 31 & M \\
\hline 6 & 46 & 7 & 47 & 6 & 86 & BM \\
\hline 7 & 29 & 24 & 47 & 6 & 25 & M \\
\hline 8 & 34 & 19 & 50 & 3 & 16 & M \\
\hline 9 & 18 & 35 & 43 & 10 & 29 & M \\
\hline 10 & 33 & 20 & 40 & 13 & 65 & M \\
\hline 11 & 42 & 11 & 53 & 0 & 0 & M \\
\hline 12 & 26 & 27 & 29 & 24 & 89 & BM \\
\hline 13 & 28 & 25 & 41 & 12 & 48 & M \\
\hline 14 & 0 & 53 & $\mathbf{0}$ & 53 & 100 & BM \\
\hline 15 & 22 & 31 & 28 & 25 & 81 & BM \\
\hline 16 & 43 & 10 & 48 & 5 & 50 & M \\
\hline 17 & 40 & 13 & 44 & 9 & 69 & M \\
\hline 18 & 22 & 31 & 38 & 15 & 48 & M \\
\hline 19 & 15 & 38 & 42 & 11 & 29 & M \\
\hline 20 & 14 & 39 & 38 & 15 & 38 & M \\
\hline 21 & 23 & 30 & 21 & 32 & 107 & BM \\
\hline 22 & 22 & 31 & 32 & 21 & 68 & $\mathrm{M}$ \\
\hline 23 & 36 & 17 & 49 & 4 & 24 & $\mathrm{M}$ \\
\hline 24 & 13 & 40 & 42 & 11 & 28 & $\mathrm{M}$ \\
\hline 25 & 5 & 48 & 6 & 47 & 98 & BM \\
\hline 26 & 27 & 26 & 44 & 9 & 35 & $\mathrm{M}$ \\
\hline 27 & 31 & 22 & 45 & 8 & 36 & $\mathrm{M}$ \\
\hline 28 & 42 & 11 & 50 & 3 & 27 & $\mathrm{M}$ \\
\hline 29 & 9 & 44 & 9 & 44 & 100 & $\mathbf{B M}$ \\
\hline 30 & 32 & 21 & 45 & 8 & 38 & $\mathrm{M}$ \\
\hline
\end{tabular}

Keterangan:

F : Frekuensi

P : Pertanyaan

M : Memenuhi kriteria persentase penurunan jumlah peserta yang menjawab salah lebih dari $25 \%$

BM : Belum memenuhi kriteria persentase penurunan jumlah peserta yang menjawab salah lebih dari $25 \%$

Cetak tebal : Belum memenuhi kriteria persentase penurunan jumlah peserta yang menjawab salah lebih dari $25 \%$ 
terwujudnya pelaksanaan Kampung KB di setiap kecamatan yang ada di Indonesia.

Namun terdapat 8 pertanyaan yang mengalami kesenjangan atau penurunan dalam menjawab pertanyaan materi pelatihan yang diberikan yang dapat terlihat dari hasil prestest dan postest peserta yang masih kurang dari $25 \%$ atau belum memenuhi standart target minimal yang telah ditetapkan dalam peningkatan menjawab dengan benar. Pertanyaan tersebut merupakan beberapa materi yang dapat dilakukan di lapangan atau masyarakat, dan terdapat materi tentang gambaran perencanaan operasional yang nantinya harus dijalankan. Selain itu beberapa faktor juga dapat menyebabkan hal tersebut terjadi, seperti mayoritas umur peserta yang lebih dari 50 tahun dapat memungkinkan dasar pengetahuan yang sudah tertancap dalam cara berfikir mempengaruhi dalam menjawab pertanyaan peserta.

Evaluasi pelatihan bukan hanya dilakukan dengan melihat efektivitas dan dampak setelah pelaksanaan pelatihan tetapi juga evaluasi dilakukan terhadap proses sebelum hingga pelatihan dilaksanakan. Langkah awal yang dilakukan dalam melaksanakan pelatihan yaitu merencanakan kebutuhan pelatihan. Hal ini merupakan faktor awal yang penting dalam menilai efektivitas pelatihan. (Salas \& CannonBowers, 2001 dalam Alvarez et al., 2004).

Evaluasi proses dilakukan dengan melihat kesesuaian metode pelatihan yang dipilih apakah telah sesuai dengan pelatihan yang dibutuhkan, materi pelatihan, peserta, dan beberapa hal lain yang dapat ditentukan dalam analisis kebutuhan awal program. Evaluasi program pelatihan yang dilakukan akan diketahui seberapa jauh tujuan dan manfaat pelatihan dapat tercapai bagi individu ataupun instansi.

Dalam pelaksanaan pelatihan Kampung KB, sarana dan rencana strategi yang ditentukan untuk mencapai tujuan pelatihan telah sesuai dan terpenuhi, kesesuaian tersebut dinilai berdasarkan hasil observasi ketika pelatihan berlangsung. Sarana yang disiapkan telah lengkap dan kegiatan pelaksanaan pelatihan tersusun dengan baik. Berdasarkan hasil tugas kelompok yang dipresentasikan terlihat peserta dapat memahami materi yang diberikan untuk melaksanakan kegiatan di lapangan, hasil ini dipengaruhi oleh pelaksanaan strategi dan penggunaan sarana atau bahan di dalam kegiatan nyata di lapangan pada saat kelas luar.

Secara umum penilaian dalam pelatihan dilakukan setelah 3 bulan setelah pelatihan diberikan. Hal tersebut dilakukan untuk memberikan kesempatan kepada peserta agar dapat mengimplementasikan pembelajaran yang telah didapatkan saat pelatihan di lapangan. Tingkat keberhasilan suatu pelatihan dapat dilakukan evaluasi secara menyeluruh berdasarkan beberapa kriteria, antara lain kriteria sukses yang mencakup pendapat atau persepsi peserta, kriteria perubahan yang meliputi penilaian perubahan sikap, perilaku kerja, serta kriteria sukses yang dinilai berdasarkan kinerja peserta pelatihan. Pretest dan post test peserta setelah pelatihan kerja dapat menjadi hal yang mendasar untuk desain pengembangan pelatihan selanjutnya.

\section{SIMPULAN}

Kesimpulan dalam pelaksanaan evaluasi keefektifan pelatihan Kampung KB antara lain:

1. Karakteristik peserta pelatihan mempunyai latar belakang yang sesuai untuk diberikan pelatihan.

2. Terjadi kenaikan pengetahuan berdasarkan hasil pre test dan post test sebesar 33,9\%. Dari total 53 peserta, 45 peserta mengalami peningkatan pemahaman materi yang diberikan. Peningkatan pengetahuan tentang materi pelatihan relatif tinggi, peningkatan tersebut hal tersebut di karena sebagian peserta belum pernah mendapatkan pengetahuan tentang Kampung KB sehingga pada saat pretest nilai peserta relatif rendah. Pengetahuan peserta dapat meningkat secara signifikan setelah diberikannya pelatihan, yang dapat dilihat dari tingginya nilai individu dan nilai rata-rata post-test dengan grafik kenaikan pengetahuan yang menjulang ke atas.

3. Menurut penilaian yang telah dilakukan kepada peserta pelatihan dari hasil 
analisis, sebagian besar peserta pelatihan cukup mampu menjawab materi pertanyaan pelatihan yang telah diberikan dengan kenaikan sudah lebih dari $84,91 \%$ sejumlah 45 peserta.

4. Pada evaluasi materi per butir pertanyaan terdapat beberapa materi pertanyaan yang kurang dipahami peserta, sehingga masih ada materi yang tidak ada atau kurang penurunan kesalahan. Penyelenggaraan, pelaksana, proses, serta hasil pasca pelatihan merupakan sisi suatu pelatihan yang haus dievaluasi secara berkala dan berkesinambungan, Hal tersebut dapat meminimalisir kurangnya pemahaman peserta terhadap materi yang diberikan.

Kesimpulan yang telah disampaikan ditunjang dengan data yang diperoleh peserta saat pelatihan berlangsung. Tujuan pelatihan adalah untuk meningkatkan pengetahuan dan pemahaman peserta tentang materi pelatihan Kampung KB yang diberikan. Secara umum hasil perolehan hasil belajar para peserta pelatihan sudah meningkat, hanya saja apabila dilihat dari per butir materi atau pertanyaan hasil menunjukkan lebih dari $25 \%$ pertanyaan kurang dapat dipahami peserta.

\section{DAFTAR PUSTAKA}

Arikunto, S. 2009. Prosedur Penelitian Suatu Pendekatan Praktik. Edisi Revisi 6. Jakarta: Rineka Cipta.

Arlene, 2001. Maternity Nursing: An Introduction Text/Arlene Burroughs. Gloria leifer-8 th ed. P: Cm Amerika.

Ayu, Candra Dian Paramita. 2016. Evaluasi Pelaksanaan Pelatihan Pembuatan Kerajinan Tangan. e-Journal Bisma Universitas Pendidikan Ganesha. Volume 4.

Badan Kependudukan dan Keluarga Berencana Nasional, 2015. Petunjuk Teknis Kampung KB. Jakarta. Badan Kependudukan dan Keluarga Berencana Nasional. [Online]. Avalaible athttp:// babel.bkkbn.go.id/infoprogram/Documents/ JUKNIS \%20KAMPUNG\%20KB.pdf [Accessed 28 September 2017].

Bagiyono. 2012. Evaluasi Pelatihan Teknik Mengajar Berdasarkan Model Empat
Level Evaluasi Pelatihan Kirkpatrick. Seminar Nasional VIII SDM Teknologi Nuklir Yogyakarta. halaman: 319-325.

Churohman, Miftah. 2010. Teori Prinsip dan Konsep Pembelajaran. Avalaible at http://miftachr.blog.uns.ac.id/2010/01/ teori-prinsip-dan-konseppembelajaran/ (diakses tanggal 20 Oktober2017).

Erfandi. 2009. Pengetahuan dan FaktorFaktor Yang Mempengaruhi. [Online]. Avalaible at http://forbetterhealth. wordpress.com/2009/04/19/ pengetahuan-dan-faktor-faktor-yangmempengaruhi. [Accessed 17 Oktober 2017].

Kirkpatrick, D.L. 2005. Kirkpatric's training evaluation model. Avalaible at http: //www.bussinesballs.com/ Kirkpatricklearningevaluationmodel. htm, [Accessed 23 september 2015].

Moekijat. 1981. Evaluasi Latihan bagi Pegawai Negeri. Bandung: Penerbit Sinar Baru.

Notoatmodjo, S. 2010. Ilmu Perilaku Kesehatan. Jakarta: Rineka Cipta.

Perwakilan Badan Kependudukan dan Keluarga Berencana Nasional Provisi Nusa Tenggara Barat. 2016. Kampung $K B$ sebagai wahana pemberdayaan masyarakat. Nusa Tenggara Barat. Perwakilan Badan Kependudukan dan Keluarga Berencana Nasional Provisi Nusa Tenggara Barat. [Online]. Avalaible at http://ntb.bkkbn.go.id/_layouts/mobile/ dispform. aspx? List $=8 \mathrm{c} 526 \mathrm{a} 768 \mathrm{~b} 88-44 \mathrm{fe}-$ $8 \mathrm{f} 81-2085 \mathrm{df} 5 \mathrm{~b} 7 \mathrm{dc} 7 \&$ View $=69 \mathrm{dc} 083 \mathrm{c}-$ a8aa-496a-9eb7-b54836a53e40\&ID=695 [Accessed 27 September 2017].

Perwakilan Badan Kependudukan dan Keluarga Berencana Nasional Provisi Jawa Tengah. 2016. Pembentukan Kampung KB dalam Rangka Menggemakan kembali Program KB di Kecamatan Karanggayam Kabupaten Kebumen. Jawa Tengah. Perwakilan Badan Kependudukan dan Keluarga Berencana Nasional Provinsi Jawa Tengah. [Online]. Avalaible at $<$ http:// bpsdmd.jatengprov.go.id/dinovasi/content/ pembentukan-kampung-kb-dalam-rangkamenggemakan-kembali-program-kb-dikecamatan-karanggayam $>$ [Accessed 27 September 2017]. 
Perwakilan Badan Kependudukan dan Keluarga Berencana Nasional Provisi Jawa Timur. 2017. Modul Belajar Mandiri Kampung KB 2017. Jawa Timur. Perwakilan Badan Kependudukan dan Keluarga Berencana Nasional Provinsi Jawa Timur.

Putri, Yuni Eka. 2016. Evaluasi efektivitas pelatihan marketing skills pada perusahaan asuransi PT XYZ. Skripsi. Institut Pertanian Bogor. [Online]. Avalaible at http://repository.ipb.ac.id/ handle/123456789/86744 [Accessed 26 September 2017].

Putri, Rani Pratama. 2017. Perbandingan faktor-faktor yang mempengaruhi penggunaan kontrasepsi intra uterine devices (iud) dan implant pada wanita usia subur di kecamatan sukarame kota bandar lampung. Skripsi. Universitas Lampung. Sumatra Selatan.[Online]. Avalaible at http://digilib.unila.ac.id/25316/ [Accessed 26 September 2017].
Rivai, Veithzal dan Sagala, Ella Jauvani. 2011. Manajemen Sumber Daya Manusia untuk Perusahaan dari Teori ke Praktik. Jakarta: PT Raja Grafindo.

Rae, Leslie. 2005. Using Evaluation in Training and Development/ Teknik Mengevaluasi Pelatihan dan Pengembangan, Trans. Moh. Alex Hadjid. Jakarta: PT Gramedia.

Satriono, Teguh dan Andree MKP. 2007. How to Measure 5 Levels of Training Evaluation. Jakarta: Intellectual Capital Publishing.

Sedarmayanti. 2013. Manajemen Sumber Daya Manusia, Reformasi Birokrasi, dan Manajemen Pegawai Negeri Sipil. Bandung: PT. Refika Aditama.

Buku kumpulan artikel:

Alvarez, Kaye, et al. 2004. An Integrated Model of Training Evaluation and Effectiveness. Human Resource Development Review, Volume III, pg. 385-416. 